\title{
How psychiatrists can win friends and influence people
}

\author{
Liz Leicester \& Stephen M. Lawrie
}

\section{COMMENTARY ON... HOW PSYCHIATRISTS CAN ENGAGE WITH THE MEDIA}

\begin{abstract}
SUMMARY
We highlight and briefly expand on what we consider some particularly important messages from Claire Bithell's article, including the importance and influence of public engagement, the rewards of talking to the media and the availability of some helpful resources.
\end{abstract}

\section{DECLARATION OF INTEREST}

L.L. is Media and Communications Manager at the Royal College of Psychiatrists.

Claire Bithell's excellent article gives a very helpful summary of how journalists operate, and explains the importance of engaging with the media as a way of communicating with the public (Bithell 2014 , this issue). We would like to highlight some key points and provide other practical pointers.

\section{The Royal College of Psychiatrists' press office database}

Like Bithell, we strongly encourage people to consider joining the Royal College of Psychiatrists' database of media spokespeople. The College receives about 40-50 enquiries each week from journalists looking for a psychiatrist to provide expert comment or assist them with their research. The College has about 200 people on its database who help respond, but it is always looking for more people to join. If you are interested in joining, please email eleicester@rcpsych.ac.uk.

\section{Don't underestimate your ability}

Some psychiatrists (especially trainees) are concerned about getting involved in media work because they do not think that they are sufficiently 'expert'. Remember, however, that the level of knowledge and communication skill that is required is about the same as is needed for everyday clinical practice. Many of the queries that come to the College press office are relatively straightforward; for example, following news reports of Paris Jackson's self-harming and suicide attempt in June 2013, the Daily Mirror ran a feature about why young people self-harm. They wanted a psychiatrist to talk in general terms about the prevalence of self-harm in young people, possible causes, triggers and the support that is available. In general, if you can talk to patients and carers, and we all should be able to do that, you can talk to the media; indeed, doing one may improve the other.

\section{Everyone has to start somewhere}

Some people shy away from media work because they are concerned that they will be thrust in front of a television camera or questioned by television presenters such as Jeremy Paxman or John Humphrys. But don't worry, you can easily go your whole life without appearing on Newsnight or Radio 4! Everyone needs to start somewhere and your press office (like the College's press office) will help you build up your experience slowly, for example by first talking to a feature writer for a glossy monthly magazine, who wants to know about the causes, symptoms and treatments of depression. There are lots of opportunities to engage with the media without appearing on camera, such as giving interviews over the telephone to print journalists or assisting television companies with scripts or programme development.

\section{Media training}

People can always improve their public engagement skills and the best way to do this, other than practice, is to get some media training. Each year, the College runs a media training booth at its International Congress. Delegates are welcome to sign up for a 40-minute one-toone training session, in which they can experience being interviewed on camera and receive feedback on their performance. Not only does this increase confidence in general and reduce anxiety about
Liz Leicester started her career as a journalist and is now the Media and Communications Manager at the Royal College of Psychiatrists. Stephen M. Lawrie is Head of Psychiatry in Edinburgh University, Director of the Scottish Mental Health Research Network, and Director of the Medical Research Foundation/Medical Research Council clinical research fellowship programme for mental health (PsySTAR).

Correspondence Stephen M Lawrie, University of Edinburgh, Division of Psychiatry, School of Clinical Sciences, Royal Edinburgh Hospital, Morningside, Edinburgh EH10 5HF, UK. Email: s.lawrie@ ed.ac.uk

'See pp. 71-78, this issue. 
what you look like on television, but it can also give important personal pointers. Above all, as Bithell says, one learns to have a key message or three to get across (and to fall back on if the going gets tough and/or one is temporarily stumped for something to say). The Scottish (www.smhrn.org. uk) and English Mental Health Research networks (www.mhrn.info) and the Science Media Centre (www.sciencemediacentre.org) also have various media awareness events.

\section{Enjoy it, it's fun!}

Most psychiatrists who engage with the media find it a stimulating and rewarding experience, and it can be an enjoyable part of your work. Quite apart from the occasional joy of seeing your name in lights and young relatives thinking you are famous, there can be any number of unusual benefits. (One psychiatrist we know helped a children's television presenter overcome a fear of heights in order to walk a tightrope and was delighted to be awarded a Blue Peter badge!) Do not be encouraged to comment on individual cases though; and never breach confidentiality.

\section{The power of the media}

Articles in newspapers, magazines, on television, radio and online can reach tens or hundreds of thousands of people. Sometimes psychiatrists think that media work is a distraction from their core work as doctors. But by taking the time to talk to a journalist (sometimes just half an hour giving a short interview over the telephone or offering a quote by email), you can help deliver a positive message about psychiatry and mental health to a huge number of people.

\section{Understanding journalists}

Journalists have a poor reputation. A recent poll by Ipsos MORI (2013) shows that $89 \%$ of the British public trust doctors to tell the truth, but only $20 \%$ trust journalists. Do not forget to check journalists' identities, but remember also that they are not there to catch you out - they are just trying to tell a story (usually under time pressure) in an interesting, attention-grabbing and balanced way. Often they will need an expert to provide comment for their report. If a psychiatrist is not available, they will need to fill that slot with someone else leaving the psychiatry voice unheard.

\section{Don't worry!}

Some psychiatrists feel wary of engaging with the media - they may feel uncomfortable talking to journalists without approval from their trusts, be concerned about saying something that will 'get them into trouble' with their employer or even be worried about litigation. But people should not be deterred by such concerns. As long as one is not breaking patient confidentiality, making outrageous claims or plagiarising others peoples' work, there are no real risks. If someone is uncomfortable talking as 'a consultant psychiatrist from Middle Britain NHS Trust', they can describe themselves as being 'a member of the Royal College of Psychiatrists'.

\section{Conclusions}

So we would say: just do it! Get started and enjoy it. There are some pitfalls, as Bithell and we have highlighted, but the more psychiatrists that get involved, the better for everyone. Providing accurate information that may reduce the prejudice and discrimination our patients face daily, and demonstrating the range of work that psychiatrists do, can only be a good thing.

The College's Public Education Handbook has lots more useful tips about engaging with the media and is available on the College's website (Royal College of Psychiatrists, 2013).

\section{References}

Bithell C (2014) How psychiatrists can engage the media. Advances in Psychiatric Treatment, 20: 71-8.

Ipsos MORI (2013) Politicians trusted less than estate agents, bankers and journalists. Ipsos MORI (http://www.ipsos-mori.com/ researchpublications/researcharchive/3133/Politicians-trusted-less-thanestate-agents-bankers-and-journalists.aspx).

Royal College of Psychiatrists (2013) Public Education Handbook: Practical Advice on Working with the Media. Royal College of Psychiatrists (www. rcpsych.ac.uk/pdf/PEC\%2OHandbook,\%202013.pdf). 